\title{
GOD INFORMASJON TIL PASIENTEN
}

\section{/ helsebiblioteket.no}

Av Hege Underdal, bibliotekar og konstituert redaksjonssjef i helsebiblioteket.no

I Norge er pasienters rett til medvirkning og medbestemmelse hjemlet i lov, men dette forutsetter kunnskap. Mange tyr til Google for å finne informasjon om sin egen diagnose, men kvaliteten på det man finner er ikke alltid like god. Helsepersonell kan bidra til medvirkning ved at pasienter får korrekt og pålitelig informasjon. Her får du tips om noen kilder som kan være nyttige å kjenne til. Lenkene finnes på Helsebibliotekets side for pasientinformasjon.

\section{HELSENORGE.NO}

I juni i fjor lanserte Helsedirektoratet «helsenorge. no»-den offentlige helseportalen for befolkningen. I tillegg til informasjon om helsetjenesten, rettigheter og selvbetjeningsløsninger, inneholder portalen informasjon om forebygging, sykdom og behandling. Innholdet er produsert av Helsedirektoratet og organisasjoner som Kreftforeningen, Statens legemiddelverk og Folkehelseinstituttet. Det meste er på norsk, men det finnes også tekster på somalisk, vietnamesisk, urdu, arabisk, tamilsk, engelsk og tyrkisk.

\section{PASIENTBROSJYRER FRA BMJ}

På pasientinformasjonssiden finner du en alfabetisk inngang til cirka 200 brosjyrer om diagnoser som diabetes, ADHD, KOLS og migrene. Brosjyrene er på norsk og egnet for utskrift slik at du kan dele dem ut til pasientene dine. Originaltekstene er produsert av British Medical Journal (BMJ) og oversatt av Helsebiblioteket. Alle tekstene er kvalitetssikret av helsepersonell og innholdet er tilpasset norske forhold, for eksempel ved at navn på preparater som ikke finnes i Norge er byttet ut med navnet på virkestoffet. Flere av disse brosjyrene finnes også på helsenorge.no.

\section{INFORMASJONSFILMER}

Helsefilm.no er en portal med informasjonsfilmer utviklet ved Sørlandet sykehus HF. Filmene er sortert i kategoriene kropp, sinn og mestring. Temaene spenner bredt: her finnes alt fra bruk av inhalatorer til akuttbehandling av hjerneslag. Målgruppen er pasienter og pårørende, men filmene kan også brukes i undervisning av helsepersonell. Flere av filmene er spesielt utviklet med tanke på barn og yngre pasienter.

\section{ANATOMISK ATLAS}

Anatomisk atlas er et oppslagsverk med illustrasjoner og tekst som beskriver kroppens ulike deler og organer. Helsebiblioteket har oversatt atlaset til norsk. Ressursen er utviklet med tanke på pasienter og pårørende og kan være et nyttig hjelpemiddel for helsepersonell i møte med disse gruppene.

\section{PASIENTERFARINGER}

En annen kilde til god informasjon er ulike pasientforeningers hjemmesider, du finner lenke til en oversikt over mange av dem på pasientinformasjonssiden. Både Norsk Revmatikerforbund, Landsforeningen for hjerte- og lungesyke, Kreftforeningen, Diabetesforbundet og Norges Astma- og Allergiforbund har utarbeidet egen informasjon til pasienter og pårørende. Pasientinformasjonssiden lenker også til ulike typer nettsteder relatert til pasienterfaringer, som HealthTalkOnline og PatientsLikeMe. Her kan brukere fra hele verden komme i kontakt med andre i samme situasjon, dele erfaringer, stille spørsmål og få råd om mestring av egen sykdom. Begge er på engelsk, men det finnes liknende forum og nettverk hos noen av de norske pasientforeningene.

\section{SPRÅKPERMEN}

Språk kan være en utfordring i kommunikasjonen 
med pasienter og pårørende. Under «Språkverktøy» på pasientinformasjonssiden finnes «Språkpermen», utviklet ved Sykehuset Innlandet HF. Dette er et enkelt, men nyttig hjelpemiddel for å kommunisere med pasienter eller pårørende som ikke snakker norsk. Her kan du for eksempel krysse av for at du vil fortelle en pasient at hun må faste fra et bestemt klokkeslett før narkose, og få teksten frem på skjermen på det språket du har valgt. Det er også mulig å få teksten lest opp. Blant språkene finnes både russisk, urdu, arabisk og somalisk, for å nevne noen.

\section{ANDRE SPRÅK ENN NORSK}

Som nevnt har helsenorge.no pasientinformasjon på andre språk enn norsk, men det finnes også andre nettsteder. MedlinePlus er amerikanske National Institutes of Health sin side for pasienter og pårørende. Her kan du enten gå inn via språk eller via tilstand og finne brosjyrer du kan skrive ut og gi til pasienter slik at de kan sette seg inn i egen tilstand på sitt morsmål. MedlinePlus ligger også under «Språkverktøy» på Helsebibliotekets pasientinformasjonsside. For pasienter som mestrer engelsk kan pasientbrosjyrene i det anerkjente oppslagsverket UpToDate være nyttige. Den avanserte bruker kan også ha glede av hoveddelen i oppslagsverket og kanskje også av andre kilder som egentlig er beregnet på helsepersonell. Takket være nasjonale avtaler er det aller meste på Helsebiblioteket.no fritt tilgjengelig for hele befolkningen.

\section{KVALITETSVURDERING}

Portalen Sunnskepsis.no gir råd om kvalitetskriterier for helseinformasjon. Nettstedet er utviklet av forskere og helsepersonell i samarbeid med pasienter og andre brukere. En del av portalen hjelper pasienten med å sjekke påliteligheten av informasjon om behandling. En annen del gir en innføring i søking etter forskning, og en siste gir tips om hva som kan være nyttig å spørre helsepersonell om. Sunnskepsis.no kan være et godt tips for pasienter så vel som helsepersonell, på leting etter pålitelige kilder.

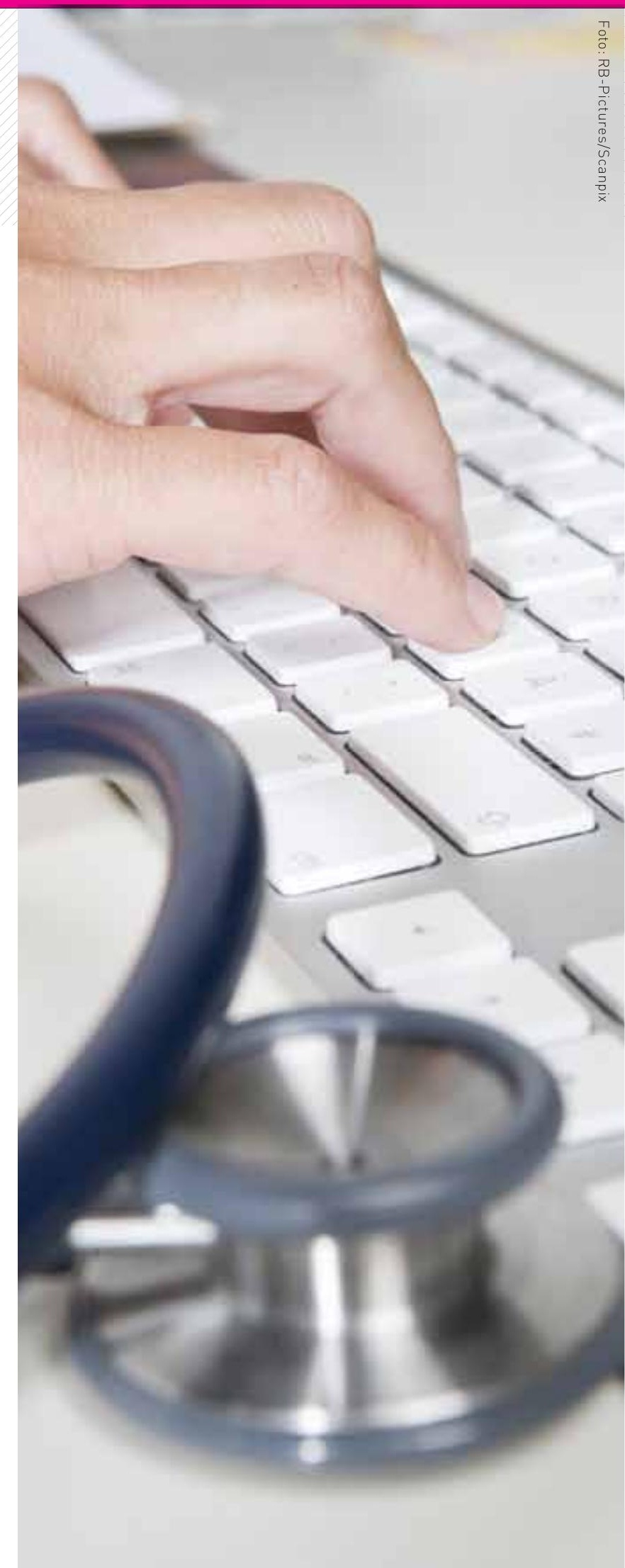

